\title{
The Development of Flipped-Blended Model of Computer Application Course in Higher Education
}

\author{
Seipah Kardipah \\ Faculty of Economics, STIE Muhammadiyah Jakarta, Indonesia \\ Department of Educational Technology, Postgraduate Programme, Universitas Negeri Jakarta, Indonesia
}

\section{Basuki Wibawa*}

Department of Educational Technology, Postgraduate Programme, Universitas Negeri Jakarta, Indonesia

*Corrosponding author's Email: bwibawa@unj.ac.id

\section{Rese a r ch High Iight s}

This study presents a new flipped-blended instructional model to enhance students' computer skills. Instructional videos, worksheets, and lecturer guidance were developed by researcher. Based on the results, the model were effective to enhance students' computer skills, The model also motivated students with difficult tasks.

\section{Research Objectives}

This study attemps to develop and examine the effectiveness of Flipped-Blended instructional model for Computer Application Course.

\section{Methodology}

This study was a research and development (R\&D) of a flipped-blended instructional model for Computer Application Courses. The study followed Steps of System Approach Model of Educational Research and Development by Gall, Gall, and Borg (2007). The model was developed and evaluated by experts and students. Six experts were involved to evaluate this 


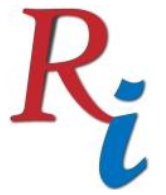

Asia Proceedings of Social Sciences

(APSS)

www.readersinsight.net/APSS

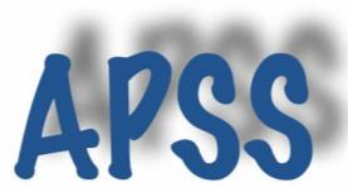

model. The trial of the model was conducted by lecturers and students after the revision of the model was completed. A total of 24 students from Muhammadiyah Economics School Jakarta also participated in this study. A single group pretest-posttest design was used. The means of the pretest and posttest were determined to find the effectiveness of the flippedblended model. The attitude survey questionnaire was used to explore the students' attitude towards the flipped-blended model for Computer Application course and interviews with students were administered to find more information about the students' attitudes and perceptions.

\section{Results}

A paired sample t-test showed that there was a statistical significant difference in the means of pretest $(M=54.64)$ and posttest $(M=83.27)$. They were significantly different by 28.63 with p-value less than alpha level $(\alpha=.05)$, indicating an improvement due to the treatment. The flipped-blended model were effective to enhance students' performance (Arnold-Garza, 2014; Hajji, Bouzaidi, Douzi, \& Khouya, 2016; Hsu, Chen, Chang, \& Hu, 2016; Nouri, 2016). Based on the questionnaire result, students felt that learning in the flipped-blended learning environment were challenging, but they were sure they can handle it well.

\section{Findings}

Interactions in flipped-blended models took place both online and in classroom. The online interactions occurred on Whatsapp application. According to the students, Whatsapp usage was easier and faster because the messages were received and replied immediately. Meanwhile, interactions in the classroom occured fairly often because the lecturer goes around the class to help students who are in trouble. This happens because the lecture material is presented outside the classroom so that the lecturers and students have more time to complete tasks (Bergmann \& Sams, 2012; Cockrum, 2014; Fulton, 2014). Various concepts can be more easily understood by students in the classroom by completing the assigned tasks. The results of the interview shows that students prefer complicated assignments to easy assignments. Complicated assignments were also motivated students to learn (Alderman, 2004). Students have become accustomed to easy assignments because they have done the easy assignments which were given outside the classroom. Students also more motivated in flipped-blended learning environment (Shinaberger, 2017; Turan \& Guktas, 2018).

\section{Acknowledgement}




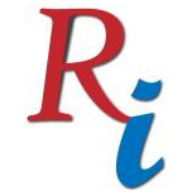

\section{Asia Proceedings of Social Sciences (APSS) \\ www.readersinsight.net/APSS}

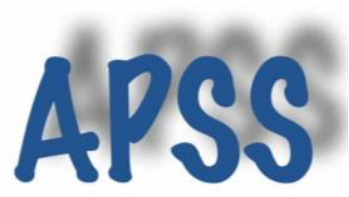

This research work is supported by The Ministry of Research, Technology, \& Higher Education, Republic of Indonesia (Doctoral Dissertation Research scheme).

\section{References}

Alderman, M. K. (2004). Motivation for Achievement: Possibilities for Teaching and Learning (2nd ed.). New Jersey: Lawrence Erlbaum Associates.

Arnold-Garza, S. (2014). The Flipped Classroom Teaching Model and Its Use for Information Literacy Instruction. Communications in Information Literacy, 8(1), 7-22.

Bergmann, J., \& Sams, A. (2012). Flip Your Classroom: Reach Every Student in Every Class Every Day. Oregon: International Society for Technology in Education. https://doi.org/10.1111/teth.12165

Cockrum, T. (2014). Flipping Your English Class to Reach All Learners: Strategies and Lesson Plans (Kindle). New York: Taylor and Francis.

Fulton, K. L. (2014). Time for Learning: Top 10 Reasons Why Flipping the Classroom Can Change Education. Thousand Oaks: SAGE Publications.

Gall, M. D., Gall, J. P., \& Borg, W. R. (2007). Educational Research. Boston: Pearson.

Hajji, M. El, Bouzaidi, R. D. El, Douzi, H., \& Khouya, E. H. (2016). New Blended Learning Strategy Based on Flipped- Learning for Vocational Work-Linked Training. Journal of Education and Practice, 7(36).

Hsu, S.-D., Chen, C.-J., Chang, W.-K., \& Hu, Y.-J. (2016). An Investigation of the Outcomes of PGY Students' Cognition of and Persistent Behavior in Learning through the Intervention of the Flipped Classroom in Taiwan. Journal PLoS ONE, 11(12).

Nouri, J. (2016). The flipped classroom: for active, effective and increased learning especially for low achievers. International Journal of Educational Technology in Higher Education, 13(1). https://doi.org/10.1186/s41239-016-0032-z

Shinaberger, L. (2017). Components of a Flipped Classroom Influencing Student Success in an Undergraduate Business Statistics Course. Journal of Statistics Education, 25(3).

Turan, Z., \& Guktas, Y. (2018). Innovative Redesign of Teacher Education ICT Courses: How Flipped Classrooms Impact Motivation? Journal of Education and Future, 13.

Note: We may include 1 or 2 references of your paper reviewers before publication if you want to be part of our Connecting Asia Reseach citation network. 


\section{Asia Proceedings of Social Sciences} (APSS)

www.readersinsight.net/APSS

Peer-review under responsibility of $4^{\text {th }}$ Asia International Conference 2018 editorial board (http://www.utm.my/asia/our-team/) (C) 2018 Published by Readers Insight Publisher, lat 306 Savoy Residencia, Block 3 F11/1,44000 Islamabad. Pakistan,

This is an open access article under the CC BY-NC-ND license (http://creativecommons.org/licenses/by-nc-nd/4.0/). 